DOI: https://doi.org/10.24867/13FA05Cvijanovic

\title{
STRATEGIJA MODELOVANJA KOMPLEKSNIH SAMONOSIVIH FORMI ZA FABRIKACIJU OD BIORECEPTIVNIH MATERIJALA
}

\section{STRATEGY FOR MODELING COMPLEX SELF-SUPPORTING STRUCTURES FOR FABRICATION FROM BIORECEPTIVE MATERIALS}

\author{
Nenad Cvijanović, Bojan Tepavčević, Fakultet tehničkih nauka, Novi Sad \\ Oblast - DIGITALNE TEHNIKE, DIZAJN I \\ PRODUKCIJA U ARHITEKTURI I URBANIZMU \\ Paviljon sagrađen od ovakvog betona može postati deo \\ zelene javne površine bez troškova zalivanja i održavanja, \\ kreirajuči svoj samostalni, mikroflorni ekosistem.
}

Kratak sadržaj - Tema ovog rada se bavi strategijom modelovanja kompleksne samonosive forme od bioreceptivnog betona

Ključne reči: Bioreceptivni materijali,modelovanje

Abstract - The topic of this thesis deals with the strategy of modeling complex selfsupporting forms made of bioreceptive concret.

Keywords: Bioreceptive material, modeling

\section{UVOD}

Danas više od polovine svetske populacije živi u gradovima [1]. Gusta gradska infrastruktura ne ostavlja mnogo prostora prirodi a zagađen vazduh kao direktna posledica toga je pojava sa kojom se suočavaju svi veći gradovi. Osim zagađenog vazduha, dva najčeća problema ovakvih sredina su nedostatak javnih zelenih površina i urbano propadanje.

Ovaj rad analizira upotrebu paviljonskih, samonosećih struktura od bioreceptivnog materijala kao efektivan način rešavanja nedostatka zelenila i neadekvatno rešenog prostora u urbanim sredinama.

\subsection{Potreba za istraživanjem}

Implementacija zelenila u gustim gradskim oblastima postala je veoma tražena s obzirom da javni zelene površine pozitivno utiču na biodiverzitet, klimu i kvalitet vazduha. Štaviše zelene površine igraju kritičnu ulogu u hlađenju gradova [2].

Već postoje razna ekološka arhitektonska rešenja za problem nedostatka zelenih površina u gradovima. Međutim ne postoji mnogo primera ekoloških paviljonskih struktura koje bi potencijalno mogle doprineti ozelenjavanju javnih površina.

Upotrebom bioreceptivnog betona kao primarnog materijala za izgradnju paviljona bi se postigao ekološki efekat . Izmenom fizičkog i hemijskog svojstva tradicionalnog betona, proizvedena je nova vrsta biološki prihvatljivog betona. Ovaj beton podstiče i održava rast mikroorganizama kao što su mahovine, lišajevi i alge direktno na njegovu površinu i tako stvara pokrivač od organskog materijala.

\section{NAPOMENA:}

Ovaj rad proistekao je iz master rada čiji mentor je bio dr Bojan tepavčević, red.prof.

\subsection{Problem istraživanja}

Bioreceptivni paneli su komplikovani za modelovanje jer njihove forme povećavaju ukupnu površinu koja bi trebala da bude nastanjena bioloskim materijalom.

Samonosiva struktura od betona zahteva složene pristupe modelovanju, gde je potrebno napraviti kompleksne panele koji drže jedan drugog.

Postojeći alati za generisanje samonosivih formi kao sto su alati u Rhinou (Rhinoceros) nemaju mogućnost modelovanja odgovarajućih površina koje prate datu formu. Najbolje rešenje za taj problem je Tissue plugin $u$ okviru Blendera.

Tako da je osnovni problem istraživanja na koji nacin generisati panele koji se mogu fabriko-vati od betona kako bi se mogli lako i fleksibilno menjati i generisati panelizacija pogodna za bioreceptivne betone.

\subsection{Cilj istraživanja}

Cilj istraživanja jeste razvijanje strategije modelovanja za generisanje ekspresivnih oblika samonosivih paviljona od bioreceptivnog betona. Pristup je baziran na analizanju postojećih primera vertikalnog ozelenjavanja sa akcentom na bioreceptivne strukture i shodno tome os-misliti strategiju na koji način se može postići vizuelna kompleksnost panela koju biorecep-tivnost zahteva.

\section{ZELENI OMOTAČI U GRADOVIMA}

Količina javnih zelenih površina u velikoj meri varira između gradova širom sveta. Njihovo povećavanje ili kreiranje, poseban je izazov tamo gde postoji pritisak na prostor, resurse i razvoj. Razvijen je niz strategija koje integrišu vegetaciju $i$ druge fotosintetske sisteme $u$ zgrade. Oni pružaju pasivnu klimatsku kontrolu smanjenjem atmosferskog $\mathrm{CO} 2$, i utiču na stvaranje novog ekološkog staništa.

\subsection{Vertikalno ozelenjavanje}

Vertikalno ozelenjavanje predstavlja gajenje biljaka na zidovima i fasadama objekata. Biljke mogu postavljati na već postojeće kao i na nove objekte. Velika je potražnja za uključivanjem inovativne zelene tehnologije za arhitektonsko i građevinsko projektovanje. Zeleni krov i zeleni zidovi su izuzetno popularni među projektantima zbog svojih estetskih karakteristika i održivog karaktera. 
Postoji mnogo vrsta vertikalnog ozelenjavanja. Generalno se mogu podeliti u dve glavne kat-egorije: Zelene fasade $\mathrm{i}$ Zeleni zidovi [3].

Međutim zeleni zidovi imaju i svoje nedostatke. Veoma su zahtevni za održavanje i potreban im je izuzetno razrađen sistem zalivanja što dovodi do visokih troškova. Odatle dolazi potreba za efikasnijim tehničkim rešenjima koji bi trebali da budu ekonomski isplativiji.

\subsection{Bioreciptivno ozelenjavanje}

Proces integracije mikroflore u strukturu zahteva stvaranje održivog odnosa između biljnog sveta i građevinskog materijala. Proučavanje prirodne kolonizacije građevinskog materijala obično se gleda sa negativnog stanovišta.

Termin biorecptivnost u stvari predstavlja osobine materijala neophodne za pričvršćivanje i dalji razvoj vegetacije na materijalnim površinama kao što su poroznost, hrapavost, vlaga i hemijski sastav površinskog sloja.

I pored svega toga, uspešnost biokolonizacije ne zavisi samo od svojstava materijala već i od uslova okoline kao što su temperatura, svetlost, voda i izloženost materijala ovim izvorima. Iako nije do kraja istraženo zašto je baš kamen najviše prijemvčiv za kolonizaciju, prostim posmatranjem može se zaključiti da je to zbog osobina kamena kao što su hrapavost površine, brazde i propustljivost. Saznaja o bioreceptivnosti prirodnog kamena su dovoljna da nam približe osnove potrebne za proučavanje drugog materijala kojim će se ovaj rad baviti a to je bioreceptivni beton.

\subsubsection{Bioreceptivni beton}

Beton je najčešće korišćeni građevinski materijal. Međutim, imajući u vidu štetan uticaj kon-vencionalnog betona na životnu sredinu, građevinska industrija je u konstantnom procesu pronalaženja alternative koja bi bila ekološki održiva.

Istraživanje na bioreceptivnim betonskim fasadama je u fazi primene na niz građevinskih ili infrastrukturnih površina kako bi se analizirale dugoročne performanse ovog inovativnog dizajna. Usvajanje biološki prihvatljivog betona kao sredstva za podsticanje zelenog rasta ima potencijal da sama fasada zgrade postane plodno tlo za rast fotosintetskih sistema.

\subsubsection{Analiza dizajna bioreceptivnih panela}

Inspiracija za ovaj rad nastala je nakon upoznavanja sa projektom bioreceptivnih panela la-boratorije BiotA. Njihov jedinstven izgled i funkcionalnost postali su inspiracija za kreiranje paviljona koji bi bio u službi estetike i ekologije. Tvorci ovih panela koristili su paterne koji se pojavljuju u prirodi kao polaznu tačku oblika fasade. U dizajnu betonske fasade možemo prepoznati strukturu koji podseća na koru drveta.

\section{SAMONOSEĆE STRUKTURE}

Samonoseće strukture su jedno on najstarijih i najelegantijih tehnika za izgradnju zakrivljenih formi. One imaju sposobnost da izdrže težinu materijala od kojeg su izgrađeni i mogu se videti kroz istoriju najvše u obliku lukova, svodova i kupola. Danas, uz pomoć kompijuterskih alata koji automatizuju proračune i razvoju materijala, samonoseće strukture mogu imati kompleksnu formu i kao takve su veoma popularne [4].

\subsection{Istorijski razvoj}

Definisanje formi $\mathrm{i}$ istraživanja njihovih mehaničkih osobina vršena su pomoći manuelnih tehnika i izradom fizičkih modela. Podelu analognih tehnika za pronalaženje forme moguće je izvršiti na analitičke i eksperimentalne. Analitičke metode mogu biti geometrijske i ma-tematičke, dok u eksperimentalne metode spadaju obrnuti viseći modeli, zategnute i pneumatske membrane. U kreativnim procesima je moguće koristiti i ostale metode, koje strogo uzevši, ne pripadaju nekoj od predhodne dve kategorije kao što su skulpturalne forme, simu-lacije oblika ljuski iz prirode, itd [5].

\subsection{Savremeni pristup}

Tehnološkim razvijanjem računara i njegovog softvera danas se pronalaženje forme vrši digitalnim putem. Digitalne simulacije omogućavaju efikasna, fleksibilna istraživanja, često na interaktivnim osnovama. Njihova prednost je u daleko jednostavnijoj manipulaciji modelima, varijaciji parametara a rezultati se mogu neposredno koristiti za strukturalnu analizu, kao i za procese digitalne proizvodenje. Od 1960-tih do danas razvijen je veći broj metoda. Nesumnjiva prednost primene ovih tehnologija i transformacija od analognih tehnika privukla je interesovanje projektanata. Ovo razmatranje fokusirano je na procedure i alate koji su pogodni za korišćenje u fazi koncepcije arhitektonskih objekata [5].

\section{PARAMETARSKI METOD MODELOVANJA SAMONOSIVIH STRUKTURA PRIMENOM TISSUE DODATKA}

Tissue dodatak se sastoji od više alata koji su namenjeni za digitalni dizajn od kojih je naj-popularniji alat Teselacija (Tessellate). Teselacija omogućava korisniku da kopira izabrani objekat (Komponenta) na lica (faces) aktivnog objekta (Generator), prilagođavajući njegov ograničavajući okvir obliku poligona. Ažuriranje (Refresh) omogućava da se aktivni objekat menja u skladu sa promenama komponenate i generatora. Na ovaj način će se modelovani paneli uklopiti na strukturu čime se postiže željeni cilj dobijanja samonosećeg paviljona omogućavajući laku iteraciju objekta.

\subsection{Generisanje forme}

Generisanje forme paviljonske strukture koja će služiti kao generator za Tissue dodatak se dobija ekstrudovanjem plane-a tako da se dobije zeljeni oblik u osnovi. Prilikom modelovanja veoma je važno voditi računa o topologiji mreže poligona. Topologija mreže koja je odgo-varajuća za rad podrazumeva da model bude sastavljen od četvorougaonih poligona sa post-ojanjem singularnih tačaka na mestu račvanja kako bi kasnije paneli pratili taj oblik.

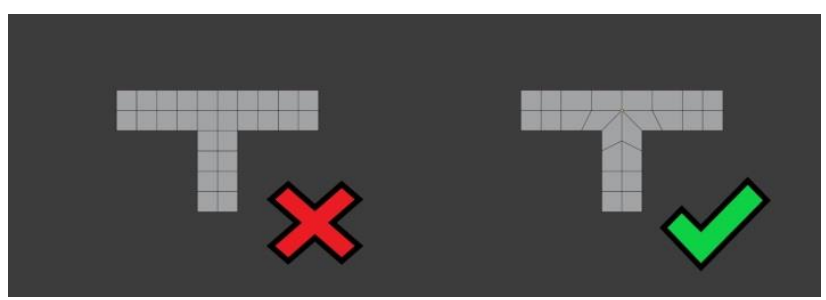

Slika 1. Prikaz normalne topologije (levo) i poželjne topologije sa singularnim tačkama na mestu račvanja (desno) 
Oslonci objekta se definišu kreiranjem vertex grupe koji sadrži informacije manuelno selektovanih vertexa koji su određeni da budu pričvršceni na površinu.

Vertex grupa kreira weight mapu uz pomoć koje se mogu videti vertexi koji su odredjeni da budu oslonci strukture. Mapa predstavlja gradient na objektu od crvene do plave boje, gde crveno predstavlja vertekse koji pripadaju zadatoj vertex grupi i može se videti njihov celokupan uticaj na objekat.

Generisanje oblika vrši se pomoću cloth simulacije i invertovane sile gravitacije. Cloth simulacija prouzrokuje relaksaciju objekta osim zadatih oslonaca slično modelu visećih lanaca koji je Antonio Gaudi (1852 - 1926) primenio u svojim projektima, dok invertovana gravitacija vuče objekat na gore, umesto na dole.

Visina objekta definisana je parametrima jačine gravitacije, vertex mase koja predstavlja težinu objekta, kao i faktora istezanja koji dodatno zateže ili relaksira objekat. Takođe njegova visina zavisi i od broja poligona koji objekat sadrži.

Da bi se kasnije imala kontrola na orijentaciju panela potrebno razviti teksturu tako da je veličine jednog poligona objekta i zatim tu teksturu kopirati na ostale koristeći funkciju follow active quads. Na ovaj način se lakše vidi smer u kome će se kretati paneli a njihova orijentacija se kasnije može korigovati rotiranjem teksture u UV editoru.

\subsection{Modelovanje panela i implementiranje Tissue dodatka}

Kreiranje panela dobija se tradicionalnim modelovanjem plane-a ekstrudovanjem poligona i dodavanjem modifajera imajući u vidu njihova preklapanja. Takođe treba da sadrže karakter-istike potrebne za bioreceptivnost kao što su različita udubljenja i ispupčenja i protok vode. Kordinate panela su bitne tokom teselacije jer promenom položaja komponente, mogu promeniti izgled finalnog proizvoda.

Preporučljivo je koristiti globalni kordinatni sistem radi lakše kontrole, gde će se panel nalaziti u okviru jedne jedinice mere osim delova koji se preklapaju.

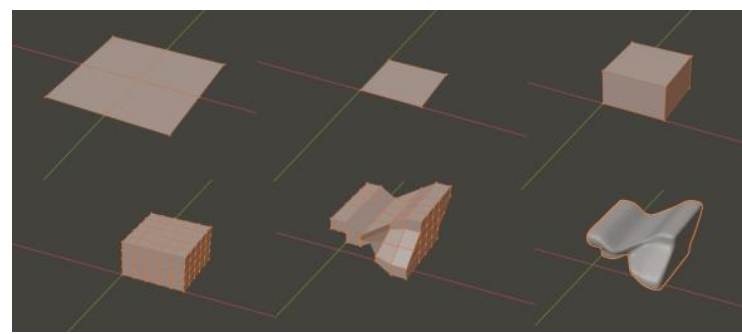

Slika 2. Vizuelni prikaz procesa modelovanja panela

Kombinovanjem izmodelovanih panela i strukrure dobija se, preko Tissue dodatka, nezavisni objekat koji sadrži karakteristike komponente i generatora.

Svaka izmena primenjena na komponentu ili generatoru, biće primenjena i na treći objekat čime se omogućava laka iteracija dizajna.

Novonastali objekat sadrži panele od komponente koji prate oblik generatora.

U edit modu se vidi da je svaki panel individualan i da se može pomerati nezavisno.

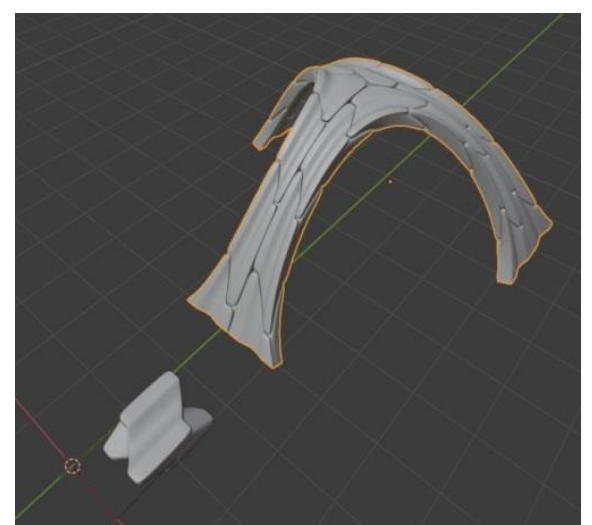

Slika 3. Prikaz novonastalog objekta

Nakon teselacije moguće su dalje izmene objekta. U slučaju da redosled panela ne odgovara, pomeranjem komponente po $\mathrm{Y}$ osi, koji je u ovom slučaju izmodelovani panel, i azuriranjem novo dobijenog objekta, redosled slaganja komponente će biti drugačiji.

$\mathrm{Na}$ isti način moguće je i podesiti broj redova panela. U ovom slučaju ako ne odgovaraju dva reda panela, skaliranjem komponente po $\mathrm{x}$ osi, tako da je ona duplo šira, dobija se efekat gde se struktura sastoji od jednog reda panela koji se slažu jedan na drugi.

$\mathrm{Na}$ ovaj način postiže se efikasan i interaktivan način testiranja različitih formi i njihovog dizajna koji pružaju brze rezultate. U zavisnosti od kompleksnosti projekta, treba obratiti pažnju na broj poligona jer znatno utiču na performanse i vreme trajanja kalkulacija.

Primenom metode rada koja je objašnjena u ovom delu rada napravljena je samonoseća struktura od bioreceptivnog betona.

\section{PRIMENA METODE MODELOVANJA NA DIZAJNU PAVILJONA NA LOKACIJI PARKA U UŠĆU NA NOBOM BEOGRADU}

Jedna od pogodnih lokacija za postavljane paviljonske strukture nalazi se na području parka u ušću na Novom Beogradu. Iako lokacija sadrži dosta zelenila, prostor nije adekvatno uredjen. Veliki, otvoreni prostor sa manjkom prirodnog hlada utiče na broj prolaznika tokom letnjeg perioda. Takođe ne postoji tačka interesa koja bi privukla ljude da provode vreme u parku. Paviljonska struktura koja bi se nalazila u centru parka, između šoping centra UŠĆE i Muzeja Savremene Umetnosti, potencijalno bi povećala frekvenciju prolaznika i turista.

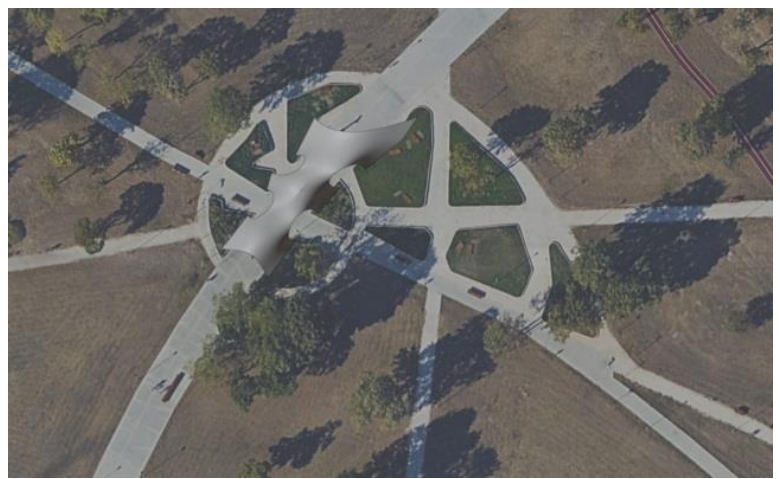

Slika 4. Prikaz strukture iz ptičije perspective 
Paviljonska instalacija sadrži šest lukova od kojih su najniži lukovi na krajevima paviljona visine 3 metra dok su bočni lukovi visine oko 6 metara omogućavajući komotan prolaz prolaznika.

Struktura se sastoji od 240 individualnih panela koji se međusobno preklapaju na svojim krajevima, čineći strukturu samonosivom ne koristeći veziva.

\subsection{Fabrikacija i montaža}

Svaki panel na paviljonu se razlikuje tako da pravljenje istih predstavlja problem. Izlivanjem betona u kalupe je jedan on načina ali bi taj proces bio sveobuhvatan i komplikovan zato što je potrebno praviti za svaki panel poseban kalup. Vreme potrebno da se naprave kalupi, zatim da se u njih izlije beton predstavlja dug proces.

Iz tog razloga bolje rešenje za fabrikaciju bilo bi $3 d$ štampa primenom industrijskog robota- Robotskom 3d štampom moguće je betona precizno praviti komplikovane oblike i strukture ne urušavajući njihov integritet.

Način montiranja paviljonske strukture se može uraditi po uzoru na projekat FaBRICKate koji je napravio studio ADAPT (Architectural Design Association of Portugal and Turkey) postavljanjem dva sloja potkonstrukcije. Prvi sloj potkonstrukcije bi sačinjavala waffle struktura od drvenih lučnih greda koje prate formu.

Na nju bi se postavljale tanke čelične šipke koje bi služile kao armatura čineći drugi sloj, preko kojih bi se slagale betonske ploče. Ovim načinom građenja paviljonska struktura bi postigla ciljani oblik.

\subsection{Vizuelni prikaz paviljona}

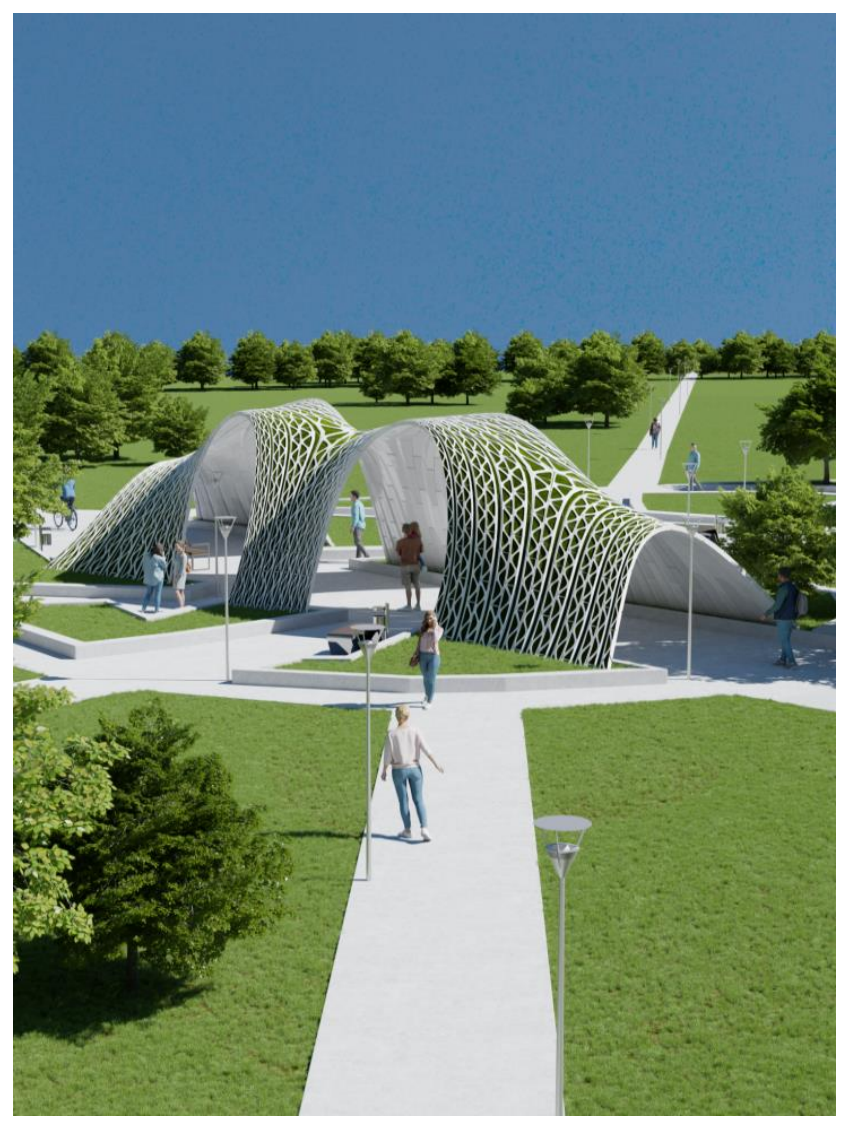

Slika 5. Prikaz treće varijante panela

\section{ZAKLJUČAK}

Istraživanjem bioreceptivnog betona i razumevanjem njegove vizuelne kompleksnosti ustanovljeno je da se korišćenjem Tissue dodatka u okviru Blendera može postići geometrijska kompleksnost kakva je potrebna za bioreceptivne panele. Standardnim parametarskim alatima kao što su Rhino i Grasshopper, može se postići takva kompleksnost ali proces kreiranja koji je prikazan u ovom radu dosta je interaktivniji i brži pa je samim tim i efikasniji. Kao što je prikazano u vizuelnom predstavljanju paviljona, može se videti laka iteracija dizajna i menjanje panela koristeći Tissue.

Tissue dodatak ne može simulirati fizička svojsta objekta i ne može uzeti u obzir statiku objekta kao neki drugi $3 \mathrm{~d}$ alati. Međutim vizuelna kompleksnost koju on može pružiti definitivno ima svoje mesto u svetu digitalnog dizajna kao još jedan alat za korišćenje koji olakšava put ka finalnoj realizaciji nekog projekta.

\section{LITERATURA}

[1] Retrieved 11 10, 2020, from United Nations: https://population.un.org/

[2] Retrieved 11 10, 2020, from Growing Green Guide, The Growing Green Guide for Melbourne project is investigating the potential to transform Melbourne's roofs, walls and facades into vegetated, leafy habitats.: http://www.growinggreenguide.org/

[3] Retrieved 11 10, 2020, from Greenscreen: https://greenscreen.com/docs/Education/greenscreen_Intr oduction $\% 20$ to $\% 20 \mathrm{Green} \% 20 \mathrm{Walls}$.pdf

[4] Pottmann Helmut, Design of Self-supporting Surfaces, pages $1-5$

[5] Jelena Milošević , Izogeometrijska analiza u morfogenezi površinskih konstruktivnih sistema, pages 41-81

\section{Kratka biografija:}

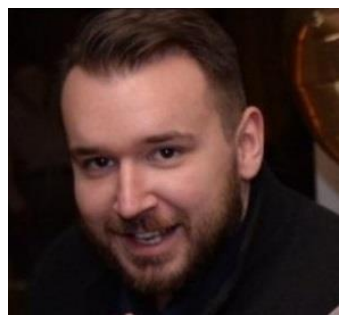

Nenad Cvijanović rođen je u Beogradu 1993. god. Master rad na Fakultetu tehničkih nauka iz oblasti Arhitekture i urbanizma Digitalne tehnike, dizajn i produkcija odbranio je 2021.god. kontakt: nenadcvijanovic93@gmail.com 